\title{
THE SPIRIT OF SOCIETY JOURNAL
}

International Journal of Society Development and Engagement

Volume 1 Number 12017

ISSN : 2597-4777 (Online) - ISSN : 2597-4742 (Print)

This work is licensed under a Creative Commons Attribution- ShareAlike 4.0 International License.

\section{Exclusive Breastfeeding Socialization Social Impacts on the Core Family and Environmental Direction}

\author{
Yogi Pasca Pratama1 , Bhimo Rizky Samudro², Ratna Dewi Kumalasari ${ }^{3}$, Anang Pra Yogi ${ }^{4}$ \\ 1,2 Fakultas Ekonomi dan Bisnis, Universitas Sebelas Maret \\ ${ }^{3}$ Ikatan Bidan Indonesia (IBI) Cabang Sukoharjo \\ 1,2,4 Researcher at Kesatuan Intelektual Masyarakat Independen (KIMI) Institute
}

yogipasca@gmail.com, bhimosamudro@yahoo.com, ratnadewi19@yahoo.co.id, prayogianang@gmail.com

\begin{abstract}
The purpose of this activity is to improve information that is known by the community in relation to patterns, ways, mechanisms of Exclusive breastfeeding. Method of implementation in the form of counseling and socialization with material about Exclusive breastfeeding, the method is coupled with simulation activities and counseling process. Success in this activity is measured by the Focus Group Discussion process aimed at identifying obstacles to exclusive breastfeeding and how problem solving does not leave local wisdom. The results of the activities are the dissemination of information to health volunteers, which are expected to assist in disseminating information on the location of each residence and in the core family of the socialization participants.
\end{abstract}

Keywords: Exclusive breastfeeding; Socialization; Health cadres.

\section{INTRODUCTION}

Government Regulation No. 33 of 2012 on Exclusive Breastfeeding in Article 6 explains that every mother giving birth has an obligation to give exclusive breastfeeding to the baby she is born with. If the conditions are not possible, described in article 7 , which causes the baby to be unable to obtain exclusive breastfeeding rights due to medical indications recommended by doctors, maternal deaths, and mothers apart from infants. Therefore, exclusive breastfeeding should still be cultivated because it is the right of the baby and the obligation for the mother.

The stability of infant's weight and baby's nutrition is one measure in looking at baby's health. The medical facts speak that enough baby weight and proper nutritional intake can be matched by breastfeeding. So breastfeeding behavior, especially exclusive breastfeeding, is a point of attention that can not be ruled out as an effort to build a healthy and quality Indonesian human being. In the end, ensuring toddlers get their rights to get exclusive breastfeeding, it also ensures that Indonesia cares about the development of healthy Indonesians who are sufficiently nutritious to become 


\section{THE SPIRIT OF SOCIETY JOURNAL}

International Journal of Society Development and Engagement

Volume 1 Number 12017

ISSN : 2597-4777 (Online) - ISSN : 2597-4742 (Print)

This work is licensed under a Creative Commons Attribution- ShareAlike 4.0 International License.

qualified human beings. Exclusive breastfeeding problems, however, are quite complicated when viewed from the many aspects that surround and ultimately provide encouragement or rejection of exclusive breastfeeding decisions.

The coverage of low breastfeeding could have an impact on the quality of life of the nation's generation as well as on the national economy. Breastfeeding in Sustainable Development Goal (SDGs) is one of the first steps for a human being to get a healthy and prosperous life. Everyone is aware of it, so for Indonesia 9 out of 10 Mothers never give milk to the baby.

\section{Urgency \& Rationalization}

Breast milk is a natural food in the form of liquid with adequate nutrients and suitable for the needs of the baby, so the baby grows and develops well. The first mother's milk is a clear yellowish liquid (colostrum), very good for the baby because it contains immune substances against the disease. Exclusive breast milk is given to infants aged 0-6 months without providing additional food or other beverages.

The advantages of breast milk are as follows: contains nutrients according to the baby's need for growth and physical development and intelligence; contain immune substances, protect babies from allergies; safe and secure hygiene, because it is immediately fed to the baby in a fresh state, will never be stale, has the right temperature and can be given anytime and anywhere; helps improve the reflexes of sucking, swallowing and baby breathing

The objectives of SDGs that are closely related to breast milk are as follows: (1) Exclusive breastfeeding can contribute around 302 billion USD each year to the world's economy. This is of course in line with the objectives of SDGs No. 1, 8, and 10 that is to eradicate poverty, economic growth and reduce injustice within and between countries. (2) The best source of nutrition can be obtained from breastfeeding activities with bioactive composition that can improve maternal and child health status, this is in line with the objectives of SDGs number 2 and 3, namely the prevention of hunger, health problems and welfare. (3) higher IQ and better performance will be obtained by babies who get breast milk with gold standard baby food so that have a decent job and income, which in the end of course continuous with goal of SDGs number 4 that is guarantee equal distribution of quality education. (4) Equality of rights and obligations between men and women in childcare will also be obtained from exclusive breastfeeding which is in line with the goal of SDGs number 5 namely gender equality. (5) Breastfeeding may also reduce the expenditure of households destined for infant formula, which is in line with the goal of SDGs number 12, which is responsible consumption.

The achievement is important for national life, it is necessary to develop and develop human resources as the basic capital of national development. Community involvement becomes the "key" to the success of the achievement foundation that has been declared by the government. 


\section{THE SPIRIT OF SOCIETY JOURNAL}

International Journal of Society Development and Engagement

Volume 1 Number 12017

ISSN : 2597-4777 (Online) - ISSN : 2597-4742 (Print)

This work is licensed under a Creative Commons Attribution- ShareAlike 4.0 International License.

\section{LITERATURE REVIEW}

\section{Human Development}

Three development goals according to Todaro and Smith (2011) are, firstly realize the increasing availability and expansion of the distribution of essential necessities of life. Both seek to improve decent living standards. Third, seek to expand the economic and social choices available to individuals and the nation as a whole.

Economic development is no longer a matter of economic growth. Amartya Sen reveals (in Todaro and Smith, 2011) that economic growth should not be viewed as a goal because development must pay more attention to improving the quality of life and freedom that we enjoy. Increasing income per capita is not an end goal, but how development policies can facilitate human beings in improving the quality of life is more feasible.

Mubyarto (2000) asserts that the shift from the stage of economic development to human development is important, because then there will be a shift in the development paradigm from which it emphasizes economic growth to growth through equity.

\section{Health in Human Development: Exclusive Breastfeeding Position}

According to Effendi (in Raharjo, 2015) explains that the formation of qualified human resources includes two dimensions, namely, qualitative and quantitative dimensions. It also includes physical and non-physical aspects and requires adequate health and nutrition programs. In this regard, the exclusive Breastfeeding Initiation (IMD) and exclusive breastfeeding program is a program that has a large proportion of the development of qualified human resources(Wulandari, n.d.).

Raharjo (2015) added that breast milk has a big role in the formation of children's intelligence, so success in breastfeeding is a valuable investment in the development of quality human resources. It also explains that breastfeeding efforts in supporting human resource quality improvement in the future are not a neglected incident, but require a systematic effort from the government.

Based on Government Regulation No. 33 of 2012 About Exclusive Breastmilk, ASI is defined as a secretion of maternal gland secretion. Raharjo (2015) added that breast milk proved to be the best food for babies, complete nutritional content to meet the nutritional needs for babies with a balanced.

The types of breast milk (Chumbley, 2003), among others:

a. Colostrum (Collostrum)

The first type is colostrum (Collostrum). Colostrum produced nursing mothers in the first few days after childbirth. This type of milk is very rich in protein and antibodies, and very thick. After the baby is born and the mother begins to breastfeed, the amount of colostrum the mother eats is very little, maybe just a teaspoon. But this is not a problem because it needs a baby with a very small size of the stomach only 


\section{THE SPIRIT OF SOCIETY JOURNAL}

International Journal of Society Development and Engagement

Volume 1 Number 12017

ISSN : 2597-4777 (Online) - ISSN : 2597-4742 (Print)

This work is licensed under a Creative Commons Attribution- ShareAlike 4.0 International License.

a number of it. This fluid contains many antibodies, inhibitors of growth of viruses and bacteria, proteins, vitamin A, and various minerals so it is recommended to be given to infants (Afifah, 2007).

b. Foremilk

The second type of milk is called foremilk. This type of breast milk is stored in the breast feeding channel of the breast-feeding mother, so it will come out at the time the baby starts feeding on her mother. Foremilk produced nursing mothers amounted to quite a lot because it serves to eliminate the thirst of infants who want to suckle at his mother.

c. Hindmilk

The third type of milk is called hindmilk. This type of milk comes out after the foremilk is sucked out by the baby or when the breastfeeding process is almost complete. Hindmilk has advantages in its content, which is very rich, thick, and full of fat vitamin. Therefore it is important to know especially breastfeeding mothers to breastfeed their babies to completion or when the baby is feeling full and release the feeding.

Breastfeeding is the process of giving milk to infants with breast milk from the mother's breast, while the baby trying to suck in order to get milk (Utami, 2011). in the Explanation of Government Regulation No. 33 of 2012 on Exclusive Breastfeeding, explained how the best feeding patterns for infants from birth to 2 years old. This explanation is also related to the pattern of breastfeeding described earlier. Breastfeeding is best for infants according to this government regulation, among others:

a. Breastfeeding the baby immediately within 1 (one) hour of birth or termed Early Breastfeeding Initiation (IMD).

b. Giving only breast milk from birth to 6 months or termed as exclusive breastfeeding.

c. Provide proper Breastfeeding Food (MP-ASI) from the age of 6 (six) months.

d. Continue breastfeeding until the child is 2 (two) years old

The explanation of PP No. 33 of 2012 on Exclusive Breastmilk provides an explanation of some of the benefits of breastfeeding. From a health perspective, breastfeeding can reduce the risk of acute infection such as diarrhea, pneumonia, ear infections, haemophilus influenza, meningitis and urinary tract infections. Breastfeeding also protects babies from diseases that could potentially infect babies after growing up, such as type 1 diabetes and type 2 diabetes.

This Government Regulation also explains that breastfeeding during infancy is associated with a decrease in blood pressure and prevents overweight and obesity in adolescence and adulthood. In addition breastfeeding can delay the return of a woman's fertility and reduce the risk of postpartum hemorrhage, breast cancer, pre menopause and

ovarian

cancer. 


\section{THE SPIRIT OF SOCIETY JOURNAL}

International Journal of Society Development and Engagement

Volume 1 Number 12017

ISSN : 2597-4777 (Online) - ISSN : 2597-4742 (Print)

This work is licensed under a Creative Commons Attribution- ShareAlike 4.0 International License.

\section{Purpose of activities}

The achievement is important for national life, it is necessary to develop and develop human resources as the basic capital of national development. Community involvement becomes the "key" to the success of the achievement foundation that has been declared by the government. A clear boundary has been raised by the Directorate of Community Role of the Department of Health of the Republic of Indonesia in relation to the term cadres, ie local community members selected and reviewed by the community and able to work voluntarily.

A person who volunteers to serve the interests of society and the environment is the spearhead targeted by this Devotional Activity. Thus, society no longer acts as an object of development, but is a "partner" for development itself. Javanese culture supports the term gethok telular, or word of mouth, where the role of cadres is tested for disseminating information, adapted to local customs and culture, so that biased information can be avoided and even eliminated altogether.

\section{Development of hypothesis}

The environment has a major role in shaping the perception of breastfeeding. For example, the physical environment between urban and rural areas in information access to exclusive ASI where urban areas have advantages over rural areas, so that urban areas may be better in exclusive breastfeeding behavior. But urban and rural comparison is not that easy, as it may be that rural societies with a social and symbolic environment can exhibit better exclusive breastfeeding behavior. This is because breastfeeding in rural areas tends not to be negatively symbolized than in urban areas where breastfeeding is considered traditional and not a modern behavior.

\section{METHOD}

\section{Counseling}

In the Indonesian language, the term counseling comes from the basic word "torch" which means the giver of light in the midst of darkness. Thus, counseling can be interpreted as a process to enlighten the public about everything "not yet known (clearly)". However, the illumination is not merely "illuminating", but the illumination must be continuous until everything that is explained is understood, comprehended, and implemented by the community (Mardikanto, 1993). 


\section{THE SPIRIT OF SOCIETY JOURNAL}

International Journal of Society Development and Engagement

Volume 1 Number 12017

ISSN : 2597-4777 (Online) - ISSN : 2597-4742 (Print)

This work is licensed under a Creative Commons Attribution- ShareAlike 4.0 International License.

The essence of any development effort conveyed through extension activities, basically aimed at achieving changes in community behavior for the realization of quality improvement of life covering many aspects, whether: economic, social, cultural, ideological, political and defense and security. Therefore, the message of development that is promoted should be able to encourage or lead to changes that have the nature of 'renewal' commonly referred to as 'inovativeness' (Mardikanto, 1992).

Associated with the communication process in counseling, can be drawn the main points of understanding as follows: 1. Communication process in the counseling should be a reciprocal process and not a direct communication that is often done in the lighting process done through mass media 2. The position of extension is parallel with its clients and other stakeholders. This means that every counselor should appreciate and listen to the response given by the community who became his client in the learning process together. 3. The response given by the client does not have to be as expected of the counselor. (Mardikanto, 2001).

\section{Socialization}

According to Soekanto (1987), there are two types of socialization, namely formal and informal socialization. Formal socialization occurs through authorized institutions according to the prevailing provisions of the state, such as education in schools and military education. While informal socialization is found in the community or in the social relationship, such as between friends, friends, fellow club members, and social groups that exist in the community. The socialization agent is the party that conducts or conducts the socialization. There are four main socialization agencies, namely families, play groups, mass media, and school educational institutions.

Vembriarto (1982), concluded that socialization is a. The learning process, ie the process of accommodation by which the individual withholds, changes the impulses in himself and takes the way of life and culture of his society. b. In the process of socialization, the individual learns the habits, attitudes, ideas, patterns, values and standards of behavior in the society in which he lives. c. All attitudes and abilities learned in the process of socialization is organized and developed as a unity of the system in his personality.

\section{RESULT AND DISCUSSION}




\section{THE SPIRIT OF SOCIETY JOURNAL}

International Journal of Society Development and Engagement

Volume 1 Number 12017

ISSN : 2597-4777 (Online) - ISSN : 2597-4742 (Print)

This work is licensed under a Creative Commons Attribution- ShareAlike 4.0 International License.

This dedication resulted in increasing knowledge related to Exclusive Breast Milk. Knowledge that is transmitted through the process of counseling and socialization in the form of legal basis of breastfeeding, breastfeeding excellence, breastfeeding time and how to give it, how to breastfeed the good and right, the benefits of breastfeeding, and refreshing on the task force Cadres Health.

The benefits of breast milk are as follows: Contains nutrients according to the baby's need for physical growth and development and intelligence; Contains immune substances.; Protects babies from allergies; Safe and guaranteed hygiene, because it is directly fed to the baby in a fresh state; It will never be stale, has the right temperature and can be given anytime and anywhere; Helps improve reflexes sucking, swallowing and baby breathing.

The timing of breastfeeding and how to give it can be described as follows: Before breastfeeding the mother should be sure to breastfeed her baby and get support from the family; The baby is immediately breastfed as soon as possible no later than 30 minutes after delivery to stimulate the milk to quickly get out and stop the bleeding; Feed the baby as often as possible until the milk is released, after which breastfeeding the baby's needs, the time and duration of breastfeeding need not be limited, and breastfeed from both breasts in turn; Give only breast milk until the baby is 6 months old. After infants 6 months of age, in addition to breast milk is also provided complementary foods (milk-milk) in the form of pulverized foods and amounts appropriate to the development of baby's age; Breastfeeding continues until the baby is 2 years old.

A good and correct breastfeeding method is as follows: Before breastfeeding the baby, first wash her hands with clean water and soap; Then clean both nipples with cotton soaked in warm water first; Breastfeeding time of the baby, should the mother sit or lie down casually, the mother's mind should be in a state of calm (not tense); Hold the baby behind his shoulder, not at the base of the head; Strive for the baby's body facing the mother's body, raise the chest of the baby with the mother's breast or the bottom of the breast; Stick the baby's chin on the mother's breast; Keep the baby's nose from the mother's breast by pressing the baby's bottom with the inner mother's arm; The baby is breastfed alternately from the milk on the left, then to the right until the baby feels full; After breastfeeding, the baby's mouth and baby's cheeks are cleaned with cotton soaked in warm water; Before being put to sleep, the baby should be buried first so that the sucked air can come out by placing the baby perpendicular to the mother and slowly rubbing it back until the belch. Air will come out by itself.

The benefits of breastfeeding can be described as follows: For Mother: Establish an affectionate relationship between mother and baby; Reduces bleeding after childbirth; Accelerate the recovery of maternal health; Delaying the next pregnancy; Reduce the risk of breast cancer; More practical because breast milk is more easily given at any time the baby needs. For Baby: Babies are healthier, lithe and not crybaby; Babies do not often get sick. For Families: Practical and no need to pay for the purchase of formula milk and its equipment; It does not take time and effort to provide formula milk, such as boiling water and washing equipment. 


\section{THE SPIRIT OF SOCIETY JOURNAL}

International Journal of Society Development and Engagement

Volume 1 Number 12017

ISSN : 2597-4777 (Online) - ISSN : 2597-4742 (Print)

This work is licensed under a Creative Commons Attribution- ShareAlike 4.0 International License.

How to maintain the quality and amount of milk production are as follows: Eat balanced nutritious foods, eat lots of vegetables and fruits. Eat more than usual; Drink plenty of water at least eight glasses a day; Enough rest with a nap / lie for 1-2 hours and keep the peace of mind; Feed the baby as often as possible from both left and right breast alternately until the baby is calm and satisfied.

Some things to keep in mind to help exclusive breastfeeding success include the following: the support of husbands, parents, mother-in-law, and other families is indispensable for the exclusive breastfeeding effort for six months to succeed.

Mothers who work still can give Exclusive breastfeeding to babies, how: Give breastmilk before leaving for work; During work, the infant can still be breastfed by way of surgery before leaving for work and housed in a clean glass and closed to give to the baby at home; After work, the baby is breastfed as usual.

How to store breast milk at home is as follows: Breast milk stored at home in a cool place will last 6-8 hours; Breast milk stored in a thermos of ice cubes will last for 24 hours; Breast milk stored in the refrigerator will last 3 times 24 hours; Breast milk stored in the freezer will last for 2 weeks.

How to give breast milk that has been stored is as follows: Wash hands with soap and rinse with clean water; If breast milk is placed in a cool room, give it immediately before the shelf ends ( 8 hours); If the milk is stored in a thermos or refrigerator, the milk stored in a closed clean cup is warmed by soaking in a bowl of warm water, then wait until the milk is warm (not cold); Breast milk is given with a clean spoon, do not use bottles or pacifiers, because bottles and teats more difficult to clean and avoid confusion of the nipple in infants

\section{CONCLUSIONS AND RECOMMENDATIONS}

\section{Conclusion}

Information on exclusive breastfeeding methods and their impact on household health and economics is carried out by a community service team assisted by ASI counselors. Invited cadres are village health cadres with representatives from each hamlet in Salam Village, Karangpandan Sub-district, Karanganyar Regency. The socialization activities of good and true Breastfeeding Methods are carried out by:

1. Socialization to the Health Cadre, where the activity is performed by the team of Servant with ASI counselor by holding a meeting with the cadres in Salam Village area.

2. Counseling to cadres and representatives of newborns and pregnant citizens

3. Good and true Breastfeeding Training is done through practice method with the help of dolls, and technical assistance is directly assisted by experienced ASI counselors in their field. The evaluation model chosen to be implemented is the evaluation of outcomes, where evaluation is carried out after the extension and socialization activities are undertaken, technically by simulation and counseling process to improve the mental and the willingness of the mothers and the environment in succeeding the intended breastfeeding business. 


\section{THE SPIRIT OF SOCIETY JOURNAL}

International Journal of Society Development and Engagement

Volume 1 Number 12017

ISSN : 2597-4777 (Online) - ISSN : 2597-4742 (Print)

This work is licensed under a Creative Commons Attribution- ShareAlike 4.0 International License.

\section{Recommendations}

Based on the results of this dedication to the community, the suggestions that can be given by the devotees team are as follows:

1. Should in carrying out socialization to the Health Cadres implemented by conducting training activities directly followed by officers in the village concerned to be more effective and also can further deepen the material given.

2. In conducting exclusive breastfeeding and awareness-raising activities should be participants not only of Cadre representatives, it would be better if the training is conducted within the scope of the relevant stakeholders so as to save time and cost.

3. There is a need for more intensive assistance from health actors and cadres in the development of socialized breastfeeding methods in order to help solve the problems faced by households, especially novice households, so as to support the development of this method of breastfeeding in an appropriate manner.

4. There should be other activities besides socialization with counseling and, which will be useful for improving the skill of nursing mothers in applying the correct method.

\section{REFERENCES}

Afifah, Diana Nur. 2007. Faktor yang Berperan dalam Kegagalan Praktik Pemberian ASI Eksklusif (Studi Kualitatif di Kecamatan Tembalang, Kota Semarang Tahun 2007). Tesis, dipublikasikan. Program Pascasarjana Universitas Diponegoro. Semarang. Diakses dari https://core.ac.uk/download/pdf/11702480.pdf pada tanggal 29 Juni 2017 jam 16.23 WIB.

Chumbley, Jane. 2003. Practical parenting: Breastfeeding. London: Hamlyn Octopus. Terjemahan Susiati Puspitasari. 2004. Menyusui: Panduan Para lbu untuk Menyusui dan Mengenalkan Bayi pada Susu Botol. Jakarta: Erlangga.

Mardikanto, T. 1992. Komunikasi Pembangunan. Sebelas Maret University Press. Surakarta .1993. Penyuluhan Pembangunan Pertanian. UNS. Press Surakarta. .1994. Bunga Rampai Pembangunan Pertanian. UNS Press. Surakarta 1997. Dasar-Dasar Komunikasi Pembangunan. PT. Balai Pustaka (persero). Surakarta 2001. Redevinisi Dan Revitalisasi Penyuluhan Pertanian. Prima Theresia Pressindo. Surakarta

Mardikanto, T. 1993. Penyuluhan Pembangunan Pertanian. UNS. Press Surakarta.

Mardikanto, T. 2001. Redevinisi Dan Revitalisasi Penyuluhan Pertanian. Prima Theresia Pressindo. Surakarta 


\section{THE SPIRIT OF SOCIETY JOURNAL}

International Journal of Society Development and Engagement

Volume 1 Number 12017

ISSN : 2597-4777 (Online) - ISSN : 2597-4742 (Print)

This work is licensed under a Creative Commons Attribution- ShareAlike 4.0 International License.

Mubyarto. 2000. Membangun Sistem Ekonomi.Yogyakarta: BPFE-Yogyakarta.

Peraturan Pemerintah Republik Indonesia No 33 Tahun 2012 Tentang Pemberian Air Susu Ibu Eksklusif

Raharjo, Bambang Budi. 2015. Momentum Emas Pembentukan SDM Berkualitas (Kajian Sosial Budaya Inisiasi Menyusui Dini dan ASI Eksklusif di Masyarakat Kendal Jawa Tengah). Disertasi, dipublikasikan. Satya Wacana University Press. Salatiga. Diakses dari http://repository.uksw.edu/handle/123456789/7053 pada tanggal 3 Mei 2017 jam 14.01 WIB.

Soekanto, S. 1987. Sosiologi Suatu Pengantar. Rajawali Pers. Jakarta

Todaro, Michael P dan Stephen C. Smith. 2011. Pembangunan Ekonomi. edisi ke sebelas jilid satu. Jakarta: Erlangga.

Utami, Reni Nugraheni. 2011. Faktor-faktor yang Mempengaruhi Tindakan Ibu Menyusui dalam Penggunaan Susu Formula untuk Bayi di Kota Surakarta. Skripsi, dipubikasikan. Jurusan Sosiologi Fakultas IImu Sosial Politik Universitas Sebelas Maret. Surakarta. Diakses dari https://digilib.uns.ac.id/dokumen/detail/23291/Faktor-Faktor-YangMempengaruhi-Tindakan-Ibu-Menyusui-Dalam-Penggunaan-Susu-FormulaUntuk-Bayi-Di-Kota-Surakarta pada 20 Maret 2017 jam 23.30 WIB.

Vembriarto, St. 1982. Sosiologi Pendidikan. Yayasan Paramita. Yogyakarta

Wulandari, A. (n.d.). Influence of Education and Work Experience on Work Motivation and Job Performance at Branch Office of BANK J Trust Bank Surabaya. THE SPIRIT OF SOCIETY JOURNAL, 1(1), 12-20. Retrieved from http://jurnal.narotama.ac.id/index.php/scj/article/view/364 